\title{
Seasonal dynamics of plankton in a mountain lake in the southern Alps (Laghetto Inferiore, Switzerland)
}

\author{
Marco SIMONA*, Alberto BARBIERI, Mauro VERONESI, Stefano MALUSARDI \& Viera STRAŠKRABOVÁ ${ }^{1)}$ \\ Laboratorio Studi Ambientali, SPAA - DT, 6900 Lugano-Paradiso, Canton Ticino, Switzerland \\ ${ }^{1)}$ Hydrobiological Institute, Czech Academy of Sciences and University of South Bohemia, Faculty of Biology, Na sádkách 7, 37005 \\ Č Budějovice, Czech Republic \\ *e-mail corresponding author: marco.simona@ti.ch
}

\begin{abstract}
The pelagic populations in Laghetto Inferiore (southern Swiss Alps) were studied between 1996 and 1998 during the ice-free period. Investigations revealed a considerable number of phytoplankton species but few zooplankton species. The vertical distribution of the main species of algae shows a marked vertical stratification, with higher biomass concentrations in the deep zone. Along this profile, species in the same taxonomic class tend to be distributed at different depths, according to their specific light requirements. During the study period no clear seasonal succession of populations was observed, also because of the influence of precipitation on the biological cycles. On the whole there was a good correspondence between the biomass values of phytoplankton and those of chlorophyll-a, both in integral samples of the whole water column and in the vertical profile.
\end{abstract}

Key words: plankton succession, vertical distribution, high mountain lakes

\section{INTRODUCTION}

In oligotrophic mountain lakes, pelagic food webs often are more simple than in lowland lakes with higher trophy. Mountain lakes of glacial origin are originally fishless, but very often they are artificially stocked. Pelagic food web structure in those lakes is further modified during the acidification process (Mosello 1986; Garibaldi et al. 1987; Cammarano \& Manca 1997), often resulting in a scarcity or even extinction of zooplankton (Fott et al. 1992, 1994). The other characteristic feature of mountain lakes is a strong effect exerted by climatic drivers (Goldman et al. 1989) and other abiotic variables, which might affect the biomass and structure of phyto- and zooplankton in vertical stratification and both in seasonal and interannual dynamics (Goldman et al. 1989; Pechlaner 1971; Tilzer \& Schwartz 1976).

The Laboratorio Studi Ambientali (LSA) has been monitoring high altitude alpine lakes in Canton Ticino for about 20 years (Boggero et al. 1996; Marchetto et al. 1994). During 1996 to 1998, Laghetto Inferiore, located in Southern part of the Alps at an altitude of $2074 \mathrm{~m}$, was the object of a more detailed survey. Because of its oligotrophic conditions and low saline content, this lake was included in the European MOLAR project, which investigated the anthropogenic impact on particularly sensitive remote lake ecosystems (Patrick et al. 1998). Along with the effects of the deposition of acidifying and nutrient substances on water chemistry (Barbieri et al. 1999a), also the pelagic food webs were studied. In this paper, particular attention is paid to the structure and seasonal dynamics of phyto- and zooplankton. Ver- tical stratification of phytoplankton species structure and biomass is evaluated, together with the two-years dynamics of phyto- and zooplankton.

\section{MATERIAL AND METHODS}

Laghetto Inferiore, or Sassolo, (2074 m a.s.1.) is located in the Maggia Valley (Canton Ticino, Switzerland) in the Central Alps. It is one of a group of small natural and artificial alpine lakes, which also includes Lago Sambuco (artificial), Lago del Naret (artificial), Piccolo Naret, Lago Scuro and Laghetto Superiore, the waters of which feed Laghetto Inferiore. Basic characteristics of the lake are described by The MOLAR Water Chemistry Group (1999, this issue). The lake ba$\sin$ is of glacial origin and is roughly triangular in shape, surrounded mainly by crystalline rocks and stony detritus, and partly by pasture land and shrubs (Boggero et al. 1996).

Morphological, physical, chemical and biological data were measured in the lake, in the inflow and the outflow. Studies were performed over a two-year cycle (June 1996 - July 1997) during the ice-free seasons (June - October). In-lake samples were taken at two other occasions (March 1997 and February 1998), under a layer of ice and snow around $2 \mathrm{~m}$ thick.

The pelagic zone of Laghetto was sampled monthly. Along with the measurement of physical and chemical parameters (Barbieri et al. 1999b, this issue), integral samples on the whole water column were taken for analyses of phytoplankton, zooplankton and chlorophyll- $a$. Water transparency was determined by Secchi disc.

Phytoplankton samples were taken between 0 and $27.5 \mathrm{~m}$ depth with a summarising water sampler 
(Schröder 1969), two parallel samples were fixed on the spot with acetic lugol and with $4 \%$ formalin, respectively. On two occasions (September 1996 and June 1997) samples were also taken in a vertical profile at 12 different depths using Van Dorn bottle, at the same time as the samples for chemical analysis.

Zooplankton was collected following the procedure prescribed by MOLAR programme (Straškrabová et al. 1999, this issue): samples were collected at the deepest point of the lake, using two small nets (diameter of opening $10 \mathrm{~cm}$ ) of two different mesh sizes. $41 \mu \mathrm{m}$ mesh size was used to collect rotifers, nauplii and the young stages of copepods (ZooSmall), while the net of $200 \mu \mathrm{m}$ mesh (ZooLarge) was used for adult copepods and cladocerans. At least three hauls with each net were taken. The ZooSmall sample was fixed with acetic lugol and the ZooLarge sample with $4 \%$ formalin.

Chlorophyll- $a$ concentration was determined in similar samples like for phytoplankton analysis, after filtering on glass fibre filter (GF/C, Whatman) and extraction in $90 \%$ ethanol (DEV 1986).

\section{RESULTS}

\subsection{Hydrological characteristics}

Bulk precipitation was collected during the period 1996-97 at the station of Robiei, located South-West of the study area at a distance of about $7 \mathrm{~km}$. In both years, the monthly sums of precipitation were round $200 \mathrm{~mm}$ in January and then showed the low values (below 80 $\mathrm{mm}$ ) in March to April and also in September. The two observation periods differed considerably in the distribution of precipitation during the ice-free period. In 1996, the high monthly sums (above $450 \mathrm{~mm}$ ) were observed before and after the ice-free period, in May and in November, respectively. In 1997, on the contrary, the largest monthly quantity was measured in June, just at the beginning of the development phase of the pelagic biocenosis. Detailed data on precipitation chemistry are summarised by The MOLAR Water Chemistry Group (1999, this issue).

\subsection{Chemical characteristics}

The results of chemical analyses performed in Laghetto and its inflow and outflow are presented and discussed in detail by Barbieri et al. (1999b, this issue) and The MOLAR Water Chemistry Group (1999, this issue). Mean values of selected parameters measured during 1996-97 are shown in table 1. Mean values in inflow and outflow were calculated for the ice-free period (June-October), mean values for the lake also include the data from winter samplings below the ice-cover. The values measured in surface layer of the lake and both in in- and outflow, were rather similar, whereas the values from bottom layers differ consistently. All the chemical parameters except of nitrate showed higher values at the bottom than at the surface, which contributed to an increased density of the deep layers. With the exception of phosphate, which remains invariably near the detection limit, the concentrations of all the ions considered showed a decrease from 1996 to 1997, which is probably connected with the different hydrological characteristics of the two years.

\subsection{Phytoplankton: integral samples on the water column}

The taxa found during the survey, some of them sporadically, were classified in 35 categories (Tab. 2). Taxonomic determination was done to genus level, and where possible also to species level. The smallest algae were grouped together as nanoplankton, distinguishing between flagellate and non-flagellate forms. For the main taxa, the patterns of abundance (Fig. 1) and of biomass (Fig. 2) are shown.

Apart from the non-classifiable nanoplankton fraction, the highest algal abundance was reached, in descending order, by Chrysophyceae with Dinobryon divergens $\left(3.510^{9}\right.$ ind $\mathrm{m}^{-2}$ ), Dinophyceae with the genus Gymnodinium (2.9 $10^{9}$ ind $\mathrm{m}^{-2}$ ) and Peridinium cunningtonii $\left(0.9 \quad 10^{9}\right.$ ind $\left.\mathrm{m}^{-2}\right)$, the Chlorophyceae with Tetraëdron (2.0 $10^{9}$ ind $\mathrm{m}^{-2}$ ) and the Cryptophyceae with Cryptomonas and Rhodomonas $\left(1.210^{9}\right.$ ind $\left.\mathrm{m}^{-2}\right)$. Among Conjugatophyceae the most frequent occurring species were Arthrodesmus octocornis, Gonatozygon pilosum, and Mougeotia cf. transeani, but all in low abundances. The maximum population development usually occurs during late summer (August-September), although some peaks of Chlorophyceae, Dinobryon divergens and flagellate nanoplankton can still be observed in October. The only category, which was already abundant in July, was the non-flagellate nanoplankton (1996).

Evaluation of the total phytoplankton biomass (Fig. 2) was based on abundances and mean cellular biovolume of the single taxa: for the most frequent species, the biovolume was determined by direct measurement in the integral samples. Phytoplankton is dominated mainly by Dinophyceae of large cell size (around $10^{4}$ $\mu \mathrm{m}^{3}$ ), the other main components being small Chrysophyceae and Cryptophyceae $\left(10^{2}-10^{3} \mu \mathrm{m}^{3}\right.$ per cell). In both seasons, the annual maximum values of biomass in the integral samples were found in August (Fig. 3), and reached around $10-13 \mathrm{~g} \mathrm{~m}^{-2}$ of fresh weight or $90 \mathrm{mg}$ $\mathrm{m}^{-2}$ of chlorophyll. Seasonal variations in the contribution of the main algal groups were negligible. Except of samples taken in October 1996 and in February 1998 (under the ice), phytoplankton biomass in Laghetto Inferiore was mostly composed of Dinophyceae (57\%), with smaller contribution by Cryptophyceae (18\%) and Chrysophyceae (16\%). Only in October samples, Conjugatophyceae and nanoplankton (in 1996) reached $6 \%$ and $18 \%$, respectively.

During the survey the chlorophyll- $a$ trend in the integral samples shows a correlation with the phytoplankton biomass, with a specific content per biomass unit between $0.7 \%$ and $1.6 \%$ (Fig. 3). 
Tab. 1. Chemical characteristics of Laghetto Inferiore.

\begin{tabular}{|c|c|c|c|c|c|}
\hline 1996 & unit & INFLOW & OUTFLOW & LAKE surface & LAKE bottom \\
\hline period of measurement & & 12.06.96-18.10.96 & 12.06.96-18.10.96 & 26.07.96-18.3.97 & 26.07.96-18.03.97 \\
\hline temperature & ${ }^{\circ} \mathrm{C}$ & 8.0 & 8.1 & 7.8 & 4.3 \\
\hline $\mathrm{pH}$ & - & 6.44 & 6.56 & 6.61 & 6.82 \\
\hline alkalinity & meq $\mathrm{m}^{-3}$ & 28 & 34 & 37 & 90 \\
\hline conductivity & $\mu \mathrm{S} \mathrm{cm} \mathrm{cm}^{-1}$ at $25^{\circ} \mathrm{C}$ & 9.6 & 10.8 & 11.3 & 19.6 \\
\hline calcium & $\mathrm{g} \mathrm{m}^{-3}$ & 1.23 & 1.36 & 1.31 & 2.50 \\
\hline nitrate & $\mathrm{g} \mathrm{N} \mathrm{m}^{-3}$ & 0.21 & 0.25 & 0.23 & 0.27 \\
\hline sulphate & $\mathrm{g} \mathrm{m}^{-3}$ & 1.83 & 2.43 & 1.95 & 3.20 \\
\hline reactive phosphorous & $\mathrm{mg} \mathrm{P} \mathrm{m}^{-3}$ & 1 & 1 & 2 & 1 \\
\hline \multicolumn{6}{|l|}{1997} \\
\hline period of measurement & & $30.05 .97-9.10 .97$ & $30.05 .97-9.10 .97$ & $24.06 .97-19.02 .98$ & $24.06 .97-19.02 .98$ \\
\hline temperature & ${ }^{\circ} \mathrm{C}$ & 7.2 & 6.7 & 8.4 & 4.2 \\
\hline $\mathrm{pH}$ & - & 6.33 & 6.48 & 6.56 & 6.79 \\
\hline alkalinity & meq $\mathrm{m}^{-3}$ & 20 & 26 & 31 & 81 \\
\hline conductivity & $\mu \mathrm{S} \mathrm{cm}{ }^{-1}$ at $25^{\circ} \mathrm{C}$ & 8.5 & 9.6 & 9.6 & 17.5 \\
\hline calcium & $\mathrm{g} \mathrm{m}^{-3}$ & 0.96 & 1.15 & 1.25 & 2.33 \\
\hline nitrate & $\mathrm{g} \mathrm{N} \mathrm{m}^{-3}$ & 0.24 & 0.25 & 0.22 & 0.25 \\
\hline sulphate & $\mathrm{g} \mathrm{m}^{-3}$ & 1.60 & 1.81 & 1.75 & 2.96 \\
\hline reactive phosphorous & $\mathrm{mg} \mathrm{P} \mathrm{m}^{-3}$ & 1 & 2 & 1 & 1 \\
\hline
\end{tabular}

Tab. 2. Plankton taxa found in Laghetto Inferiore.

\begin{tabular}{|c|c|c|c|}
\hline \multicolumn{3}{|c|}{ PHYTOPLANKTON } & \multirow{2}{*}{$\begin{array}{c}\text { ZOOPLANKTON } \\
\text { Rotifera }\end{array}$} \\
\hline Cyanophyceae & Dinophyceae & Conjugatophyceae & \\
\hline Dactylococcopsis & Gymnodinium (large) & Closterium & Keratella hiemalis \\
\hline Phormidium & Gymnodinium (small) & Cosmarium & Polyarthra vulgaris-dol. \\
\hline Chrysophyceae & Peridinium cunningtonii & Mougeotia cf. transeani & Synchaeta sp. \\
\hline Dinobryon divergens & Peridinium - cysts & Staurastrum & Copepoda \\
\hline Chrysophyceae (cysts) & Dinophyceae (various) & Arthrodesmus octocornis & Cyclops abyssorum tatricus \\
\hline Mallomonas cf. areolata & Chlorophyceae & Gonatozygon pilosum & Cladocera \\
\hline Chromulinales & Oedogonium & Cryptophyceae & Acroperus harpae \\
\hline Bacillariophyceae & Chlamydomonas & Cryptomonas & \\
\hline Surirella & Coenocystis & Rhodomonas & \\
\hline Fragilaria & Elakatothrix & Tribonema & \\
\hline Achnantes & Oocystis & nanoplankton & \\
\hline \multirow[t]{3}{*}{ Navicula } & Sphaerocystis & flagellates & \\
\hline & Tetraëdron & non-flagellates & \\
\hline & Planktosphaeria & & \\
\hline
\end{tabular}

\subsection{Phytoplankton: distribution in the vertical profile}

To verify the vertical distribution of the phytoplankton population, during the sampling in September 1996, a series of samples was taken every $2.5 \mathrm{~m}$ through the water column, and the principal taxa were counted (Fig. 4).

The vertical distribution of abundance differs among different taxa, which reached their maximum development different depths. In the upper layers $(0-7.5 \mathrm{~m})$, small-sized armored Dinophyceae (Peridinium, juvenile forms?) were abundant, whereas the Chrysophyceae (Dinobryon, Mallomonas) were concentrated around 10 $\mathrm{m}$ depth, the Conjugatophyceae (Arthrodesmus, Gonatozygon) together with the large-sized Peridinium cunningtonii tab. remotum (Dinophyceae) around $20 \mathrm{~m}$, and the Chlorophyceae around $25 \mathrm{~m}$. The Cryptophyceae showed a clear tendency to develop in deep layers. They were absent in the upper $10 \mathrm{~m}$, then they increased progressively below $12.5 \mathrm{~m}$ (Rhodomonas), and further below $17.5 \mathrm{~m}$ (Cryptomonas).

This tendency for phytoplankton species to establish themselves in particular layers, mainly in lower depths (aided by the great transparency), was confirmed by the relationship between algal biomass and chlorophyll- $a$ along the vertical profile (Fig. 5), and also by the trend of the chlorophyll- $a$ profiles measured in the course of the survey (Fig. 6). Maximum chlorophyll- $a$ concentration was always found below $20 \mathrm{~m}$. Particularly interesting is the fact that the abundance of small-sized Peridinium cunningtonii (juvenile form?) in the upper layers of the lake on September 10 ${ }^{\text {th }}, 1996$, was not cor- 

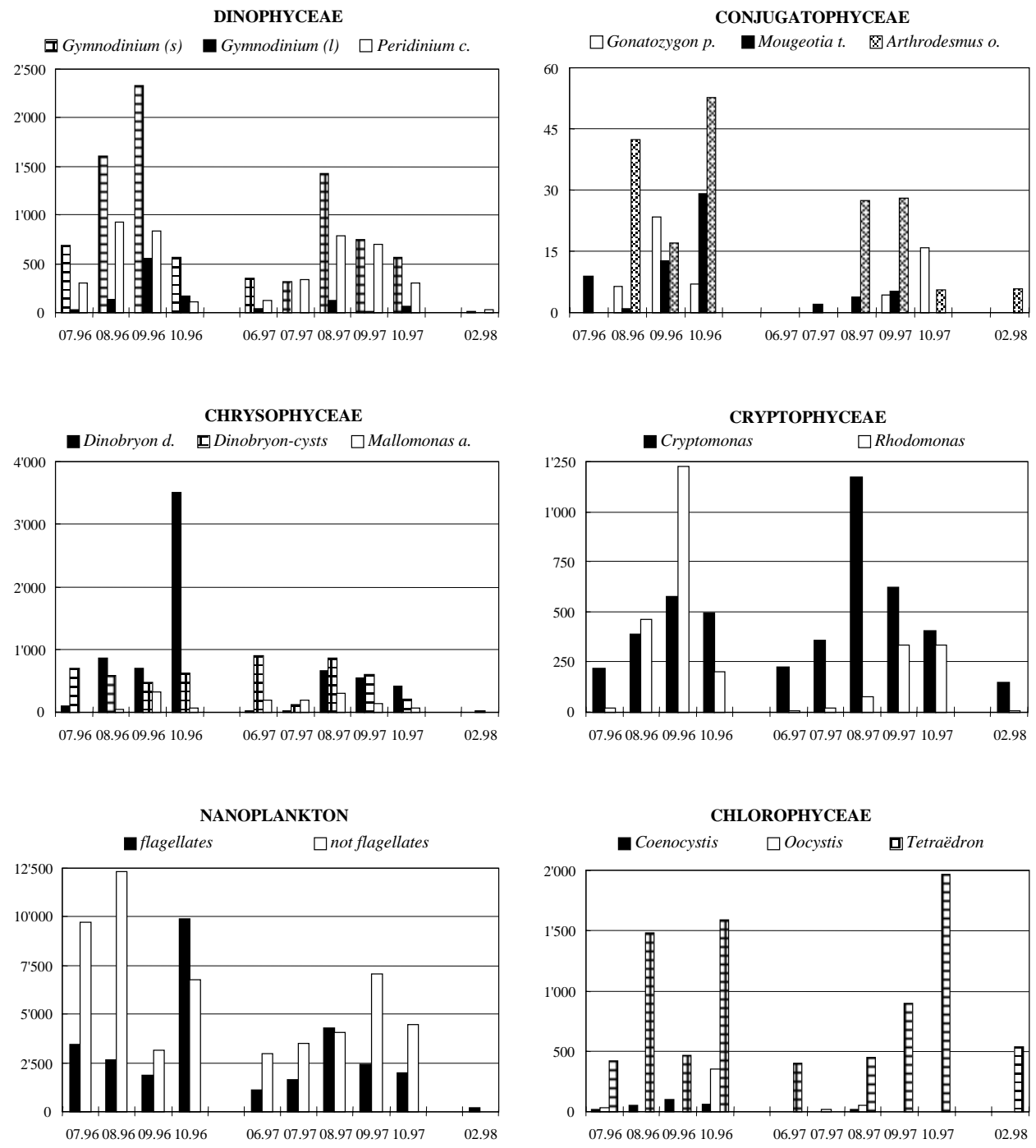

Fig. 1. Abundance of the main phytoplankton taxa $\left[10^{6}\right.$ cells $\left.\mathrm{m}^{-2}\right]$.

related with the vertical distribution of chlorophyll- $a$ (Fig. 5), which documented a lower percentage of chlorophyll- $a$ in Peridinium biomass than in the other taxa, and might be connected with the prevailing mixotrophy of that species.

\subsection{Zooplankton}

The number of zooplankton species found in Laghetto Inferiore is far lower compared to phytoplankton. Organisms of small sizes (rotifers, nauplii and young stages of copepods) in samples taken with the fine mesh net ("ZooSmall") and the adult copepods ("ZooLarge") were prevailing, whereas the cladocerans were usually present in small quantities. There were three taxa of rotifers, Keratella hiemalis, Polyarthra vulgaris-dolichoptera and Synchatea sp., and two crustacean taxa, Cyclops abyssorum tatricus and Acroperus harpae (Tab. 2).
Figure 7 shows the dynamics of zooplankton abundance over the two years of study. The highest values were reached by rotifers, with a maximum in October 1996 composed of Keratella hiemalis $\left(3.410^{6}\right.$ ind. $\mathrm{m}^{-2}$ ) and Polyarthra vulgaris-dolicoptera $\left(3.310^{6}\right.$ ind $\left.\mathrm{m}^{-2}\right)$, while in August 1997 the maximum was mainly composed of Polyarthra vulgaris-dolicoptera $\left(1.610^{6}\right.$ ind $\mathrm{m}^{-2}$ ). The only pelagic species of copepods (Cyclops abyssorum tatricus) displayed considerable densities only in 1996: at the time of greatest development (JulyAugust), values of 20-30 10 ind $\mathrm{m}^{-2}$ were reached, consisting largely of larval (nauplii) and young (C1-C5) stages. In 1997 there was a sharp reduction in the population, which was characterised by an almost complete absence of adult stages. The density values of $A c$ roperus harpae (littoral cladoceran species) remained extremely low, though their trend in both years was similar, with peaks of $200-300$ ind $\mathrm{m}^{-2}$. 
DINOPHYCEAE

- Gymnodinium (l) 䧃 Gymnodinium (s) $\square$ Peridinium c.

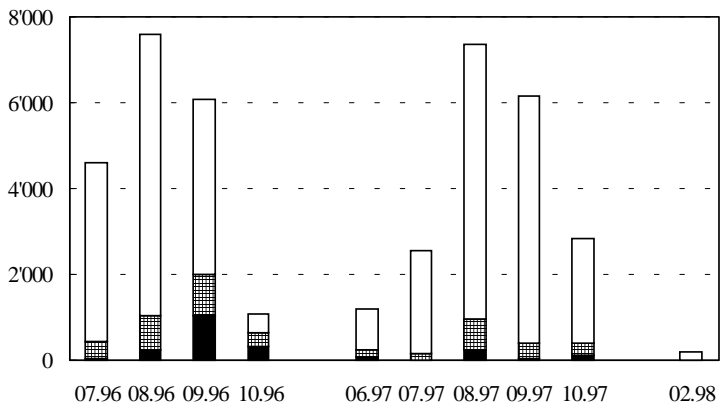

CHRYSOPHYCEAE

口 Dinobryon d. 㘞Dinobryon-cysts $\square$ Mallomonas a.

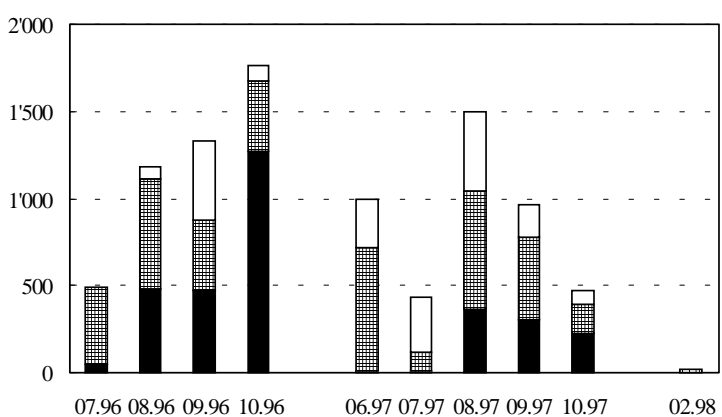

NANOPLANKTON

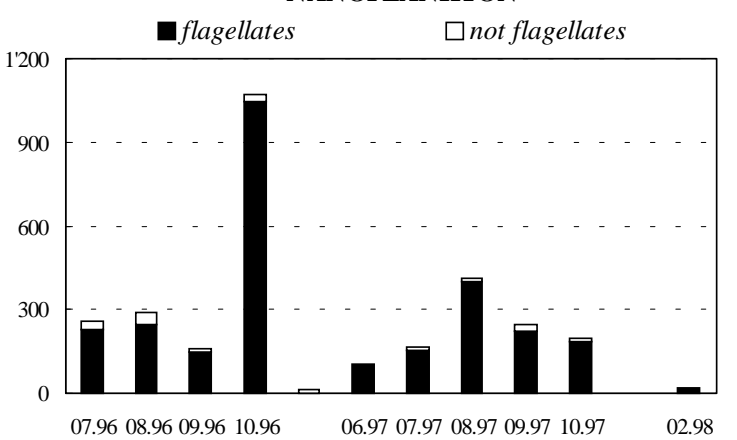

CONJUGATOPHYCEAE

$\square$ Gonatozygon p. 㖆Mougeotia t. Arthrodesmus o.

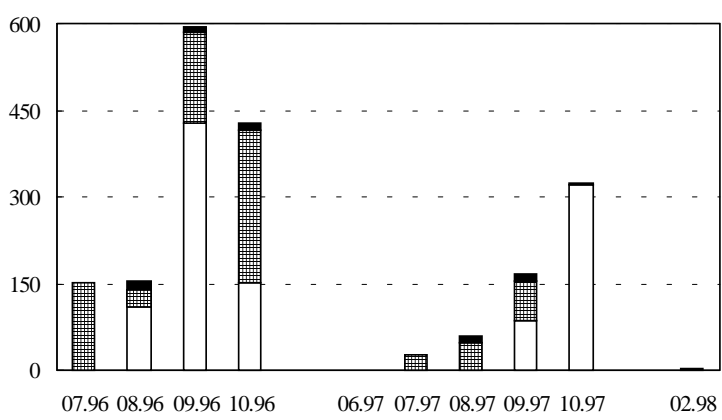

CR YPTOPHYCEAE

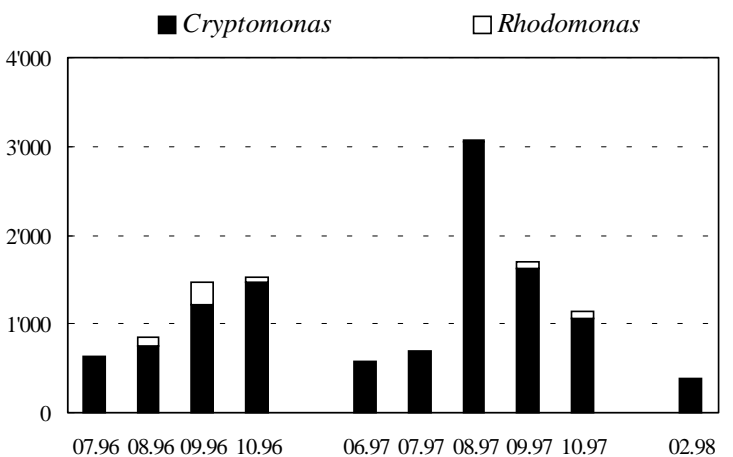

CHLOROPHYCEAE

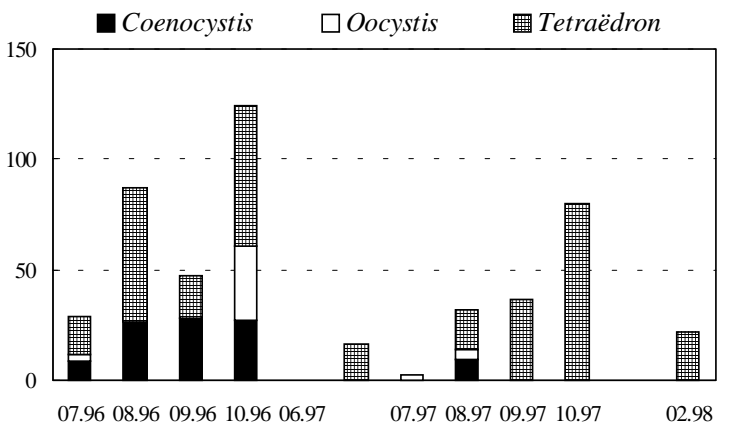

Fig. 2. Biomass of the main phytoplankton taxa $\left[\mathrm{mg} \mathrm{m}^{-2}\right.$; fresh weight $]$.

The zooplankton biomass value (fresh weight) in the pelagic zone (Fig. 8) was calculated by multiplying the abundance in each counting category by the corresponding biovolume. The contribution of rotifers usually fell between 0.5 and $1.2 \mathrm{~g} \mathrm{~m}^{-2}$, except for a peak in October $1996\left(2.7 \mathrm{~g} \mathrm{~m}^{-2}\right)$ and a sharp drop in June-July 1997 (0.1-0.2 $\left.\mathrm{g} \mathrm{m}^{-2}\right)$. The biomass of copepods (Cyclops abyssorum tatricus), on the other hand, reached significant values only in June-July $1996\left(0.6-1.3 \mathrm{~g} \mathrm{~m}^{-2}\right)$, and remained at extremely low levels $\left(<0.2 \mathrm{~g} \mathrm{~m}^{-2}\right)$ during the whole survey during 1997. The contribution of cladocerans to the total biomass was altogether negligible, due to the scarcity of the Acroperus harpae population.

\section{DISCUSSION}

The pelagic environment of Laghetto Inferiore is characterised by extremely oligotrophic conditions, which seem to have a more marked influence on the development of aquatic biocenoses than do the acidification phenomena typical of some high altitude lakes. In fact, the measured mean alkalinity appears to be able to neutralise the acidifying load, so that $\mathrm{pH}$ at the surface is kept at around neutral values (6.6 on average). 


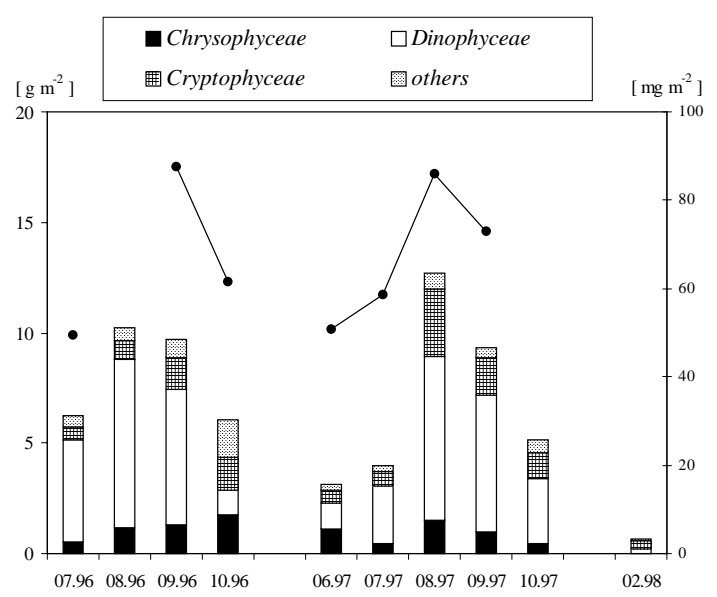

Fig. 3. Trend of phytoplankton biomass $\left[\mathrm{g} \mathrm{m}^{-2}\right]$ and chlorophyll- $a\left[\bullet, \mathrm{mg} \mathrm{m}^{-2}\right]$ on the integral sample $(0-27.5 \mathrm{~m})$.
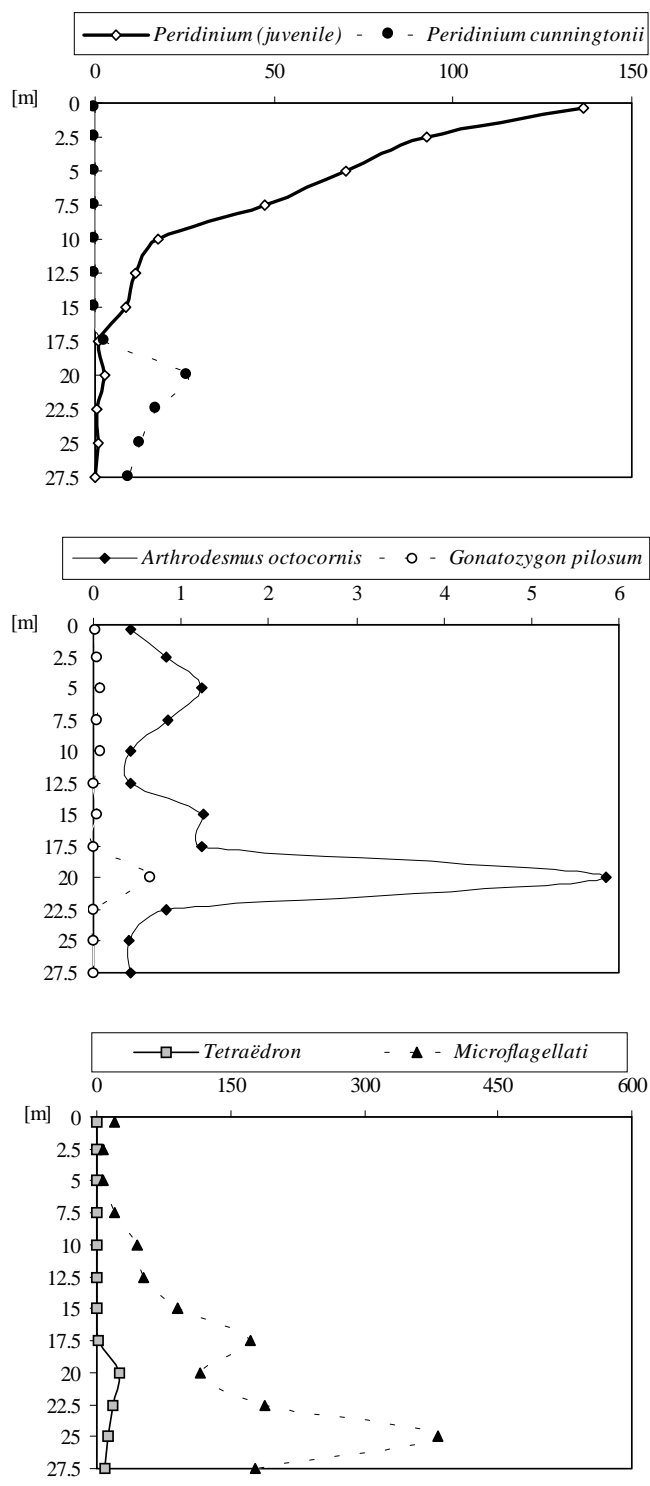

The pelagic assemblage displayed a fair variety of algal species (about thirty) and a scarcity of animal species. In particular, the crustacean zooplankton is made up of a single copepod species (Cyclops abyssorum tatricus) and one cladoceran (Acroperus harpa ), the latter typical of the littoral zone. The scarcity of crustacean zooplankton seems to be due not only to the extremely oligotrophic conditions of the lake, but also to the predator pressure exerted by artificially introduced nectonic fauna (Garibaldi et al. 1987).

However, the scarcity of crustacean taxa and prevalence of copepods above cladocerans is in concordance with the situation in other ultraoligotrophic MOLAR lakes, even if they are fishless, and this phenomenon is more pronounced with the increasing acidification (Barbieri et al. 1999b; Fott et al. 1999; Manca \& Comoli 1999; Medina-Sánchez et al. 1999; this issue). A high
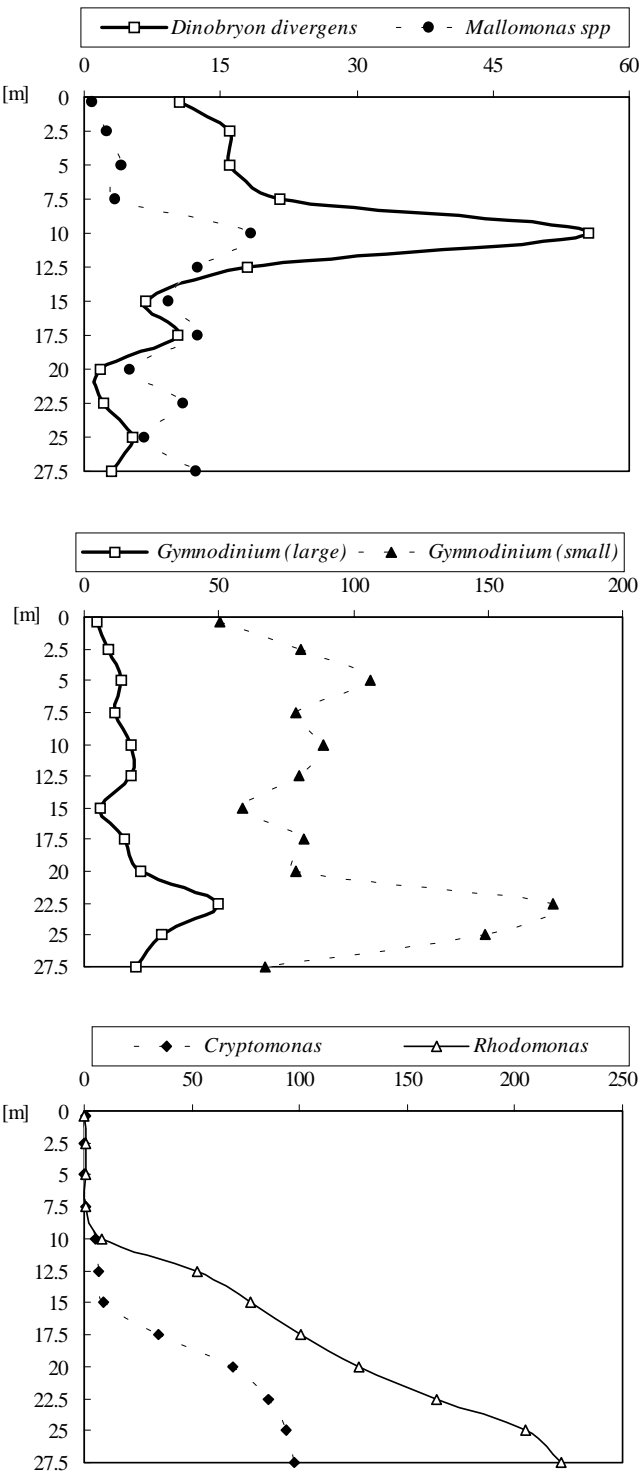

Fig. 4. Distribution of main phytoplankton taxa in vertical profile [cells $\mathrm{ml}^{-1}$ ] (September $\left.10^{\text {th }}, 1996\right)$. 
development of cladoceran biomass (even in the lakes stocked with fish) was observed in lakes with a trend to an increasing trophy [(e.g., Crosa and Alzasca with hypolimnetic oxygen deficit (Barbieri et al. 1999b, this issue), and Lago Paione Superiore with the highest ammonia + nitrate $\mathrm{N}$ concentration among MOLAR lakes located in the Alps (The MOLAR Water Chemistry Group 1999, this issue) and with the phytoplankton biomass reaching three times higher peaks than in Laghetto (Pugnetti \& Bettinetti 1999, this issue)].

The considerable difference found between 1996 and 1997 in the development of the population of $C y$ clops abyssorum tatricus in Laghetto must be seen in relation with the different hydrological trends in these two years: in particular, at the beginning of July 1997 there was a period of heavy precipitation which caused a rapid flushing of the whole water column, which at that moment was not yet stratified (Barbieri et al. 1999a).
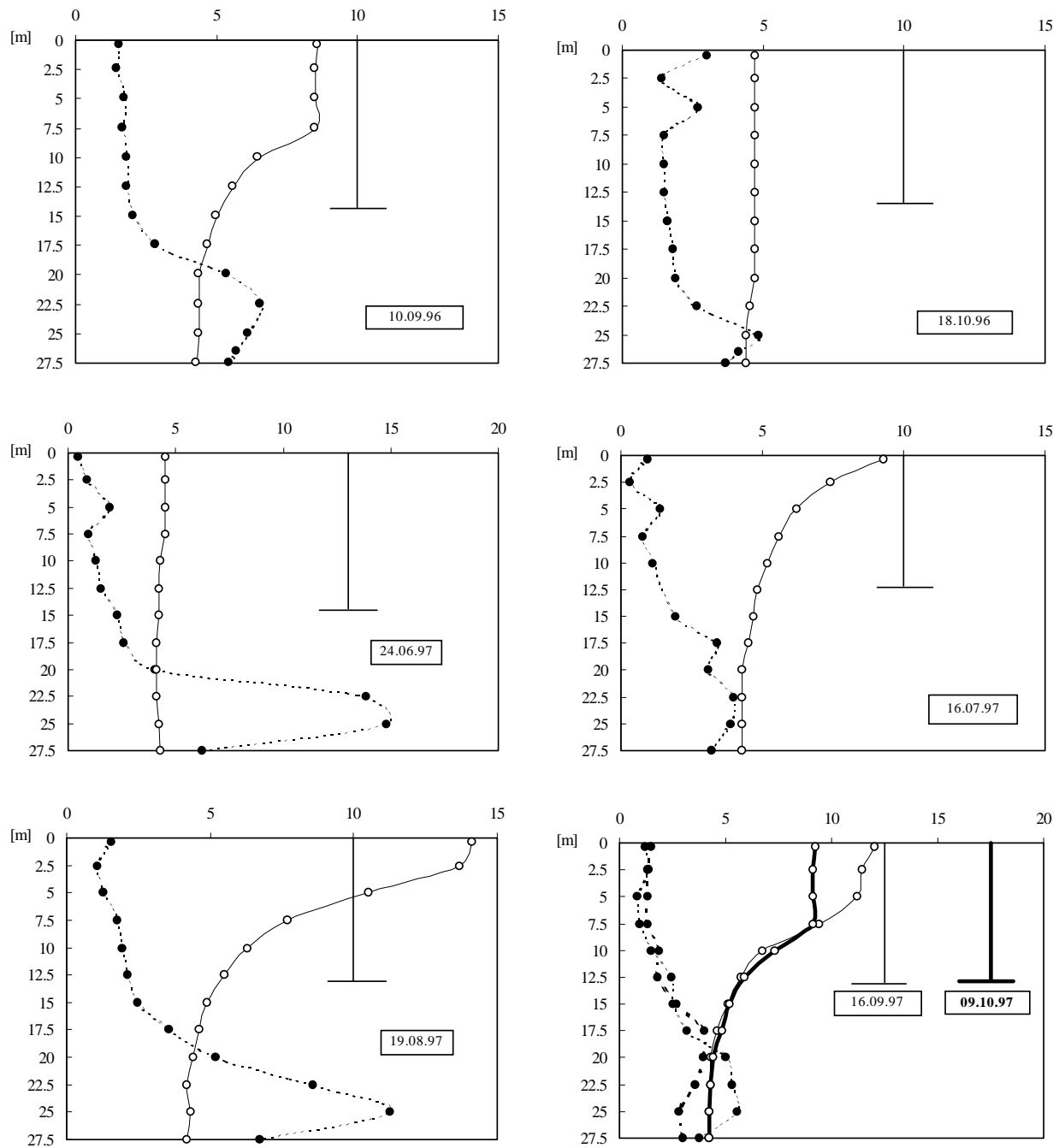

Fig. 6. Chlorophyll- $a\left[\bullet, \mathrm{mg} \mathrm{m}^{-3}\right]$, water temperature $\left[\mathrm{O},{ }^{\circ} \mathrm{C}\right]$ and Secchi-disc transparency $[\perp, \mathrm{m}]$ in the vertical profile during the 

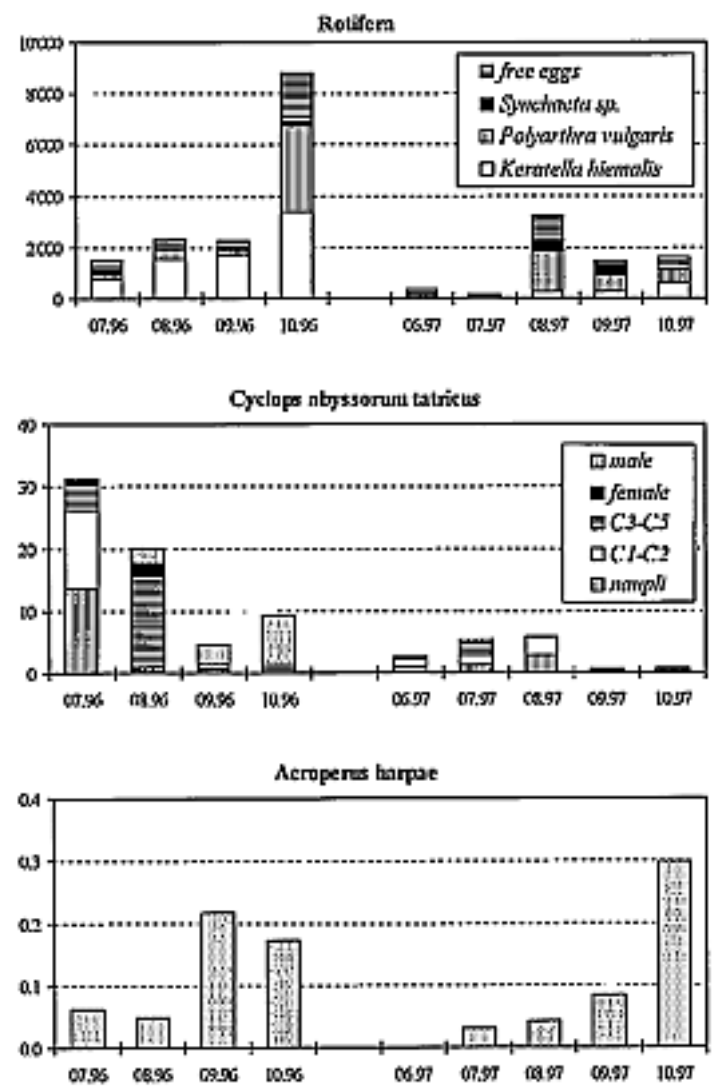

Fig. 7. Seasonal changes of zooplankton abundance $\left[10^{3}\right.$ cells $\mathrm{m}^{-2}$.

The effects of this hydrological event were evident not only in the zooplankton population but also in chlorophyll, which at the sampling on July $16^{\text {th }}, 1997$ was distributed almost homogeneously along the vertical profile. The emerging of copepodites from sediment might be affected by these unfavourable conditions. However, remarkable variations in cyclopid assemblages between years (not different in hydrology) might also be connected with a low temperature and, consequently, a slow development of crustaceans, with life cycles longer than one season as described by Nauwerck (1994) in a high latitude lake Latnajaure.

The data collected showed no evidence of a seasonal succession of single species or groups of pelagic algae: the populations usually reached their maximum development from August on, though they displayed marked fluctuations from one year to another. Flagellated taxa prevailed. The main contribution to the phytoplankton biomass comes from a limited number of species, primarily the armored Dinophyceae (Peridinium cunningtonii), followed by the flagellates Cryptomonas and Dinobryon divergens. So to achieve a correct estimate of the total biomass, it is important to verify the cell biovolume values of these species.
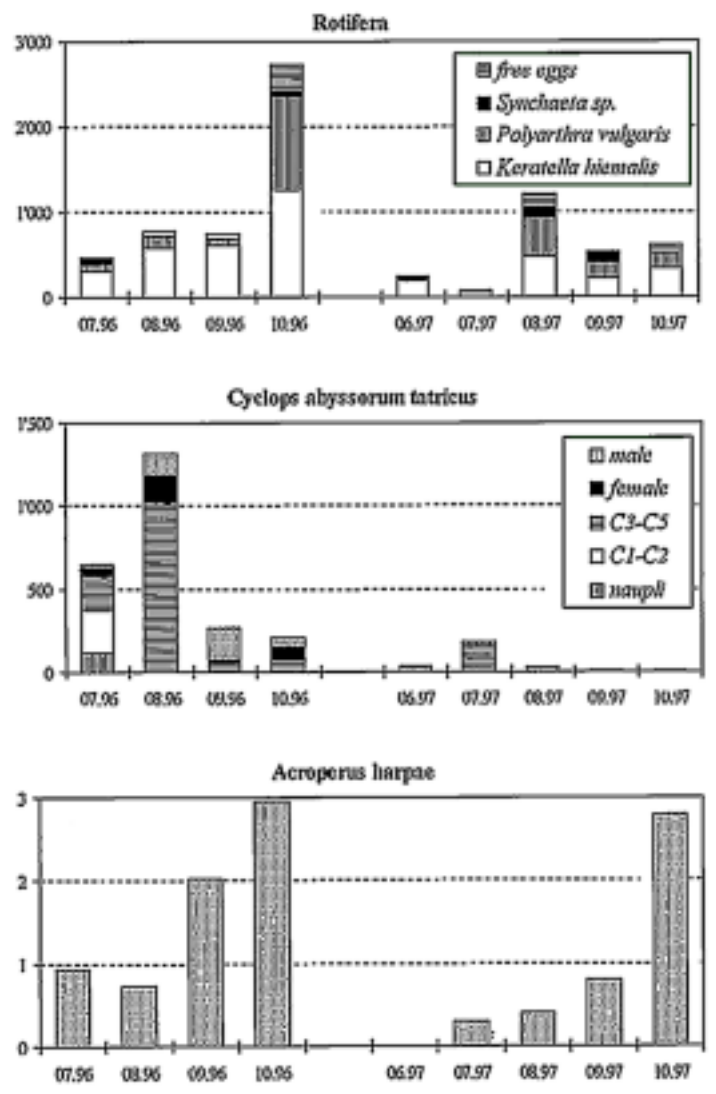

Fig. 8. Seasonal changes of zooplankton biomass $\left[\mathrm{mg} \mathrm{m}^{-2}\right.$; fresh weight].

Phytoplankton species occurring in Laghetto were similar like in other MOLAR lakes, however, the main groups in terms of biomass were different. The prevalence of representatives of Dinophyceae and Chrysophyceae during the ice-free season in Laghetto is consistent with the situation in some lakes in the Alps [Lago Paione Superiore (Pugnetti \& Bettinetti 1999, this issue), four of 7 lakes studied in Ticino Valley (Barbieri et al. $1999 \mathrm{~b}$, this issue), but differs from the other data Jörisee with prevailing Chlorophyceae (Hinder et al. 1999), Gossenköllesee with prevailing Diatomeae (Blažo, personal comm.), and even some lakes in Ticino Valley, Morghirolo, Nero, Alzasca with high percentage of Diatomeae in the total PHY biomass (Barbieri et al. 1999b, this issue)].

Due to the high altitude climatic conditions, the development of phytoplankton assemblage in Laghetto Inferiore is concentrated to the period when the surface of the water is free of ice and snow (June-October) and the solar radiation can penetrate the water column. The high transparency of water (on average about $13 \mathrm{~m}$ ) means that the photosynthesis might occur almost down to the bottom of the lake and that, apparently, photosynthesis and phytoplankton occurrence in the upper layers is light inhibited. 
One of the most interesting aspects characterising the phytoplankton biocenosis of Laghetto Inferiore regards its vertical distribution along the water column. As emerges clearly from the profile of September 1996, organisms belonging to the same class of algae tend to establish themselves at the depth which best corresponds to their specific light requirements. The upper layers ( $<10 \mathrm{~m}$ depth) are poorly colonised by phytoplankton, probably because the excessive solar radiation (UV especially) tends to inhibit their development: the only species present in considerable quantities is the small Peridinium cunningtonii (juvenile form?), presenting a low chlorophyll content. This species might be mixotrophic, similarly like Dinobryon (also known to be bacterivorous), which occurred round $10 \mathrm{~m}$ of depth (together with Mallomonas). The deepest near the bottom layer was preferred by Cryptophyceae (Rhodomonas, Cryptomonas), which are also known to be mixotrophic, though the fagotrophic behaviour was not documented. Frequent occurrence of mixotrophic algal species in this oligotrophic lake is in accordance with other data from oligotrophic lake environments (Jones 1994).

Chlorophyll measurements along the vertical profile also clearly showed a preferential development of algal biomass the deepest layers, where the attenuation of solar radiation and the release of nutrients from the sediment offer better conditions for photosynthetic activity (Schneider 1981). The peaks of chlorophyll or phytoplankton biomass in deep layers or at the bottom are characteristic in clear-water mountain lakes (Pechlaner 1971; Tilzer \& Schwarz 1976) and occurred frequently in other MOLAR lakes (e.g., Hinder et al. 1999; Pugnetti \& Bettinetti 1999; this issue).

Phytoplankton biomass in Laghetto Inferiore expressed in carbon and calculated per volume reached in the peaks $100-150 \mu \mathrm{g} \mathrm{C}^{-1}$. These are similar values like seasonal maxima found in MOLAR lakes Redó, Chuna and La Caldera, round the median value from the total range 5-2500 $\mu \mathrm{g} \mathrm{C} \mathrm{l^{-1 }}$ observed in MOLAR (Straškrabová et al. 1999, this issue). Seasonal maxima of zooplankton biomasses in Laghetto, on the other

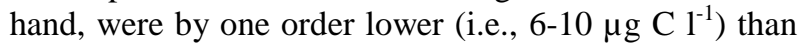
the median value found in MOLAR lakes and corresponded to the situation observed in the lakes $\varnothing_{\text {vre }}$ Neådalsvatn, Nižné Terianske and Starolesnianske (Straškrabová et al. 1999, this issue).

\section{CONCLUSIONS}

The indications emerging from this survey allow us to draw some general conclusions relevant to the study of the pelagic assemblages in high altitude lakes.

First of all, the influence of hydrological parameters on the plankton populations is striking. In particular, the flushing rate trend, which is closely linked to the precipitation regime, regulates not only the growth of the plankton (through the input of acidifying and nutrient substances) but also their removal or slower growth. In this connection the quantity as well as the time of the precipitation, during the ice-free period, are determining factors, also as regards the degree of stratification of the water column.

A further consideration concerns the spatial distribution and temporal variation of the phytoplankton populations: measurements in Laghetto Inferiore highlight a marked stratification of phytoplankton taxa along the vertical profile. This being the case, great care must be taken in the choice of techniques and sampling frequencies, so as to have a representative picture of the biocenosis. In this study, the chlorophyll values of integral samples on the whole water column $(0-27.5 \mathrm{~m})$ have always shown good correspondence with the values calculated from samples taken at different depths (every $2.5 \mathrm{~m}$ ), and on the basis of monthly samplings during the ice-free period it has been possible to get preliminary information on the population dynamics.

However, high altitude pelagic environments have a high degree of variability, so that the relationships between biotic and abiotic components can be only derived on the basis of multiannual investigations.

\section{REFERENCES}

Barbieri, A., M. Simona \& R. Mosello. 1999a. Chemical trend, recent evolution in mass budget and seasonal dynamics of a high altitude lake in southern Alps (Laghetto Inferiore, Switzerland). In: Sustainable Lake Management, $8^{\text {th }}$ International Conf. on the Conservation and Management of Lakes, 17-21 May 1999, Copenhagen-Denmark, Vol. I, S3B-4.

Barbieri, A., M. Veronesi, M. Simona, S. Malusardi \& V. Straškrabová. 1999. Limnological survey in eight high mountain lakes located in Lago Maggiore watershed (Switzerland). In: Straškrabová, V., C. Callieri \& J Fott (Eds), Pelagic food web in mountain lakes. MOuntain LAkes Research Program. J. Limnol., 58(2): 179-192.

Boggero, A., A. Marchetto, A. Barbieri, A. Sassi, M. Conedera, G.A. Tartari \& R. Mosello. 1996. Idrochimica dei laghi alpini del Canton Ticino (Alpi Centrali) in relazione con la chimica delle precipitazioni. Documenta Ist. ital. Idrobiol., 56: 273 pp.

Cammarano, P. \& M. Manca. 1997. Studies on zooplankton in two acidified high mountain lakes in the Alps. Hydrobiologia, 356: 97-109.

DEV. 1986. Deutsche Einheitsverfahren zur Wasser-, Abwasser- und Schlamm-Untersuchung; Bestimmung des Chlorophyll-a-Gehaltes von Oberflächenwasser (L 16). Losblattsammlung. VCH Verlagsgesellschaft, Weinheim.

Fott, J., M. Blažo, E. Stuchlík \& O. Strunecký. 1999. Phytoplankton in three Tatra mountain lakes of different acidification status. In: Straškrabová, V., C. Callieri \& J Fott (Eds), Pelagic food web in mountain lakes. MOuntain LAkes Research Program. J. Limnol., 58(2): 107-116.

Fott, J., M. Pražáková, E. Stuchlík \& Z. Stuchlíková. 1994. Acidification of lakes in Šumava (Bohemia) and in the High Tatra Mountains (Slovakia). Hydrobiologia, 274: 3747.

Fott, J., E. Stuchlík, Z. Stuchlíková, V. Straškrabová, J. Kopáček \& K. Šimek. 1992. Acidification of lakes in Tatra Mountains (Czechoslovakia) and its ecological significance. In: Mosello, R., B. Wathne \& G. Giussani, (Eds), Limnology on groups of remote mountain lakes: 
ongoing and planned activities. Documenta Ist. ital. Idrobiol., 32: 69-81.

Garibaldi, L., R. Mosello , B. Rossaro \& F. Setti. 1987. Caratteristiche chimiche e biologiche di due laghi d'alta quota suscettibili ad acidificazione. Documenta Ist. ital. Idrobiol., 14: 165-180.

Goldman, C.R., A. Jassby \& T. Powell. 1989. Interannual fluctuation in primary production: meteorological forcing at two subalpine lakes. Limnol. Oceanogr., 34: 310-323.

Hinder, B., M. Gabathuler, B. Steiner, K. Hanselmann \& H. R. Preisig. 1999. Seasonal dynamics and phytoplankton diversity in high mountain lakes (Jöri lakes, Swiss Alps). In: Straškrabová, V., C. Callieri \& J Fott (Eds), Pelagic food web in mountain lakes. MOuntain LAkes Research Program. J. Limnol., 58(2): 152-161.

Jones, R.I. 1994. Mixotrophy in planktonic protists as spectrum of nutritional strategies. Mar. Microb.. Food Webs, 8: 87-96.

Manca, M. \& P. Comoli. 1999. Studies on zooplankton of Lago Paione Superiore. In: Straškrabová, V., C. Callieri \& J Fott (Eds), Pelagic food web in mountain lakes. MOuntain LAkes Research Program. J. Limnol., 58(2): 131-135.

Marchetto, A. A. Barbieri, R. Mosello \& G.A.Tartari. 1994 Acidification and weathering processes in high mountain lakes in Southern Alps. Hydrobiologia, 274: 75-81.

Medina-Sánchez, J.M., M. Villar-Argaiz, P. Sánchez-Castillo, L. Cruz-Pizarro \& P. Carrillo. 1999. Structure changes in a planktonic food web: biotic and abiotic controls. In: Straškrabová, V., C. Callieri \& J Fott (Eds), Pelagic food web in mountain lakes. MOuntain LAkes Research Program. J. Limnol., 58(2): 213-222.

Mosello, R. 1986. Effect of acid deposition on subalpine and alpine lakes in NW Italy. Mem. Ist. ital. Idrobiol., 44: 117146.

Nauwerck, A. 1994. Cyclops scutifer SARS in Lake Latnajaure, Swedish Lapland. Hydrobiologia, 274: 101-114.

Patrick, S., R.W. Battarbee, B. Wathne \& R. Psenner. 1998: Measuring and modelling the dynamic response of remote mountain lake ecosystems to environmental change: an introduction to the MOLAR project. - In: Kovar, K., U. Tappeiner, N.E. Peters \&R.G. Craig (Eds), Hydrology, water resources and ecology in headwaters. Proceedings of the HeadWater'98 conference, Merano. International Association of Hydrological Sciences Publ. No. 248, IAHS Press, Wallingford: 403-410.

Pechlaner, R. 1971. Factors that control the production rate and biomass of phytoplankton in high-mountain lakes. Mitt. Internat. Verein. Limnol., 19: 123-145.

Pugnetti, A. \& R. Bettinetti. 1999. Biomass and species structure of the phytoplankton of an high mountain lake (Lake Paione Superiore, Central Alps, Italy). In: Straškrabová, V., C. Callieri \& J Fott (Eds), Pelagic food web in mountain lakes. MOuntain LAkes Research Program. J. Limnol., 58(2): 127-130.

Schneider, U. 1981. Phytoplankton und Primärproduktion in einigen Hochgebirgsseen des Kantons Tessin. Inauguraldissertation der Philosophisch-naturwissenschaftlichen $\mathrm{Fa}$ kultät. Universität Bern.

Schröder, R. 1969. Ein summierender Wasserschöpfer. Arch. Hydrobiol., 66: 241-243.

Straškrabová, V., C. Callieri, P. Carrillo, L. Cruz-Pizarro, J. Fott, P. Hartman, M. Macek, J.M. Medina-Sánchez, J. Nedoma \& K. Šimek. 1999. Investigations on pelagic food webs in mountain lakes - aims and methods. In: Straškrabová, V., C. Callieri \& J Fott (Eds), Pelagic food web in mountain lakes. MOuntain LAkes Research Program. J. Limnol., 58(2): 77-87.

The MOLAR Water Chemistry Group. 1999. The MOLAR Project: atmospheric deposition and lake water chemistry. In: Straškrabová, V., C. Callieri \& J Fott (Eds), Pelagic food web in mountain lakes. MOuntain LAkes Research Program. J. Limnol., 58(2): 88-106.

Tilzer, M.M. \& K. Schwarz. 1976. Seasonal and vertical patterns of phytoplankton light adaptation in high mountain lake. Arch. Hydrobiol., 77: 488-504. 